\title{
Risk factors and detection of brucella ovis in naturally infected rams and ewes*
}

\section{Fatores de risco e detecção de brucella ovis em carneiros e ovelhas naturalmente infectados}

\author{
Letícia Soares de Araújo Teixeira, ${ }^{* *}$ Flaviane Alves de Pinho, ${ }^{* *}$ Joilson Ferreira Batista, ${ }^{* *}$ Misael das Virgens Santana, ${ }^{* \star * *}$ \\ Francisco Felipe Ferreira Soares, ${ }^{* *}$ Ana Milena César Lima, ${ }^{* * * *}$ Leonardo Lopes Furtado, ${ }^{* * * *}$ \\ Francisca Kelly dos Santos Silva, ${ }^{* * * * *}$ Luma Martins Nunes Santos, ${ }^{* * * *}$ Tuanny Creusa Medeiros Damasceno, ${ }^{* *}$ \\ João Farias de Sousa Junior, ${ }^{* *}$ Marlene Sipaúba de Oliveira, ${ }^{* *}$ Janaína de Fátima Saraiva Cardoso, ${ }^{* \star * * * *}$ \\ Ney Rômulo de Oliveira Paula, ${ }^{* * * * * * *}$ Ana Lys Bezerra Barradas Mineiro*******
}

\begin{abstract}
The objective of this study was to verify the occurrence of ovine brucellosis using Agar Gel Immunodiffusion (AGID) and Polymerase Chain Reaction (PCR) techniques, as well as to identify the main risk factors associated with infection in sheep flocks belonging to municipalities in the microregion from Teresina, PI, Brazil. A total of 100 urine and blood samples were collected from sheep aged 6 months or older. The urine samples were submitted to conventional PCR and the blood samples were examined by the AGID technique. Of the 100 blood samples, 17 (17\%) were reactive to the AGID test. In conventional PCR of 100 urine samples, six $(6 \%)$ were positive. Risk factors associated to infection by $B$. ovis included the rearing system $(O R=0.19)$, feed management $(O R=0.05)$, presence of dystotic births $(O R=4.50)$, miscarriages $(O R=3.75)$ and source of water offered to the animals $(O R=0.19)$. Thus, it was concluded that it is possible to detect the occurrence of animals with ovine brucellosis since PCR is a reliable method to confirm infection. Furthermore, there are risk factors associated to infection by $B$. ovis in the municipalities studied.
\end{abstract}

Keywords: Brucellosis. AGID. PCR. Sheep.

\section{Resumo}

Objetivou-se verificar a ocorrência da brucelose ovina através das técnicas de Imunodifusão em Gel de Ágar (IDGA) e Reação em Cadeia da Polimerase (PCR), bem como identificar os principais fatores de risco associados à infecção nos rebanhos ovinos pertencentes a municípios da microrregião de Teresina, PI, Brasil. Foram colhidas 100 amostras de urina e de sangue de ovinos com idade superior ou igual a seis meses. As amostras de urina foram submetidas a PCR convencional e as amostras de sangue à técnica de IDGA. Das 100 amostras de sangue 17 (17\%) foram reagentes ao teste de IDGA. Já na PCR convencional das 100 amostras de urina, seis (6\%) foram positivas. Ressalta-se que três animais foram positivos em ambos os testes. Como fatores associados à infecção por $\mathrm{B}$. ovis, observou-se o tipo de sistema de criação $(\mathrm{OR}=0,19)$, o manejo alimentar $(\mathrm{OR}=0,05)$, presença de partos distócicos $(O R=4,50)$, abortamentos $(O R=3,75)$ e a fonte de água fornecida aos animais $(O R=0,19)$. Assim, conclui-se que foi possível detectar a ocorrência de animais com brucelose ovina, uma vez que a PCR é um método confirmatório. Além disso, há fatores de risco associados à infecção por $B$. ovis nos municípios estudados.

Palavras-chave: Brucelose. IDGA. PCR. Ovino.

\section{Introduction}

Ovine brucellosis is a disease of interest in animal reproduction, characterized by an infectious-contagious trait and tending to chronicity, caused by a bacteria of the genus Brucella spp, species B. ovis (Nozaki et al., 2011a). B. ovis is a Gram negative bacteria with coccobacilli morphology, wrinkled colonial form and facultative intracellular parasitism, (Nogueira; Ferrar; Curci, 2006).
This disease is also known as ovine epididymitis, because $B$. ovis is responsible for triggering inflammatory processes in the ram epididymis. Due to this damage and reproductive harm to ewes, ovine brucellosis has caused economic losses in sheep rearing. The main reproductive disturbances observed are: orchitis, miscarriages, reduced fertility in reproducer, birth of weak animals, epididymitis and perinatal death (Lima, 2015).

\footnotetext{
${ }^{*}$ Recebido em 5 de fevereiro de 2021 e aceito em 19 de abril de 2021.

${ }^{*}$ Residents of the Multiprofessional Program in Health Care, University Veterinary Hospital, Federal University of Piaui, Teresina, Piauí, Brazil.

***Teacher, Department of Anatomy, Pathology and Veterinary Clinics, Federal University of Bahia, Salvador, Bahia, Brazil.

****Postgraduate students in Animal Reproduction, Graduate Program in Animal Science, Federal University of Piaui, Teresina, Piauí, Brazil.

${ }^{* * * * *}$ Graduates of the Veterinary Medicine Course, Federal University of Piaui, Teresina, Piauí, Brazil.

******Veterinarian, Teresina, Piauí, Brazil.

*******Teachers, Department of Veterinary Clinic and Surgery, Federal University of Piaui, Teresina, Piauí, Brazil. Corresponding author: neyromulo@ufpi.edu.br
} 
The main factors associated to infection with $B$. ovis are attributed to herd size (numerous herd), no clean water available to the animals, lack of cleanliness in the installations, sharing of pasture during feeding with animals of other species, introduction of animals from unknown herds, not performing the examination to detect ovine brucellosis, not castrating rams (reduction in the number of sexually active rams and consequently decrease in venereal transmission) and no keeper for the animals (Mendonça et al., 2017).

Ovine brucellosis can be diagnosed by bacteria isolation, serological tests, for example the Agar Gel Immunodiffusion Assay (AGID), Complement Fixing (FC) and Immunoenzymatic Assay (ELISA), associated to the history of the disease in the herd (Nozaki et al., 2013; Moustacas et al., 2013). In addition to the serological methods and bacteria culture, molecular techniques have been used, such as the Polymerase Chain Reaction (PCR), which is characterized as a direct method, with high sensitivity, specificity and fast results (Costa et al., 2013; Xavier et al., 2010).

In view of the relevance of the disease in causing productive losses to sheep rearing, the occurrence of ovine brucellosis was determined by the techniques of Agar Gel Immunodiffusion Assay (AGID) and Polymerase Chain Reaction (PCR), and the main risk factors were identified associated to the infection in the sheep herds in the municipalities of the homogeneous microregion of Teresina-PI, Brazil.

\section{Material and methods}

The research was carried out by random selection from municipalities in the homogeneous microregion of Teresina, Piauí: Lagoa Alegre, José de Freitas, Teresina, Dermeval Lobão, Lagoa do Piauí, Miguel Leão, Beneditinos, Altos, Pau Darco and União. The farms were sampled randomly according to the information on the rural property register, sheep rearing, in the Piauí Agricultural Defence Agency (Agência de Defesa Agropecuária do Estado do Piauí (Adapi).) In each municipality a number of sheep herds was determined to be included randomly in the research. On each farm 10 animals of both sexes (male and female) took part randomly in the sampling process; $30 \%$ consisted of young animals ( 6 to 12 months) and $70 \%$ were adult animals (older than 12 months) totaling 100 animals distributed in the extensive, semi-intensive and intensive rearing systems. Of the 100 animals studied, 84 were females and 16 were males. There was an expected $2 \%$ disease prevalence in the samples, confidence level $95 \%$ and a variation of $5 \%$.

Because animals were used in the research, it was approved by the Commission of Ethics in the Use of Animals (CEUA) of the Federal University of Piauí (FUPI) protocol number 030/2014.

During the visits to the rural properties information was collected by questionnaires of the rearers for a sero-epidemiological survey, to identify health, reproductive, production and feed management, to which the animals were submitted, and to detect possible risk factors associated to infection with $B$. ovis. . Then, blood and urine samples were collected from ram and sheep using the jugular venipuncture method and rapid breath block, respectively. The animals studied were not submitted to experimental inoculation with $B$. ovis.
The agar gel immuno-diffusion technique (IDGA) was used to search for anti-B ovis antibodies in blood samples and urine was collected to detect the presence of the $B$. ovis bacteria DNA by the PCR technique. The tests were carried out in the Laboratory of Animal Reproduction Physiopathology and the Veterinary Microbiology Laboratory at the Federal University of Piaui (FUPI).

The blood samples were collected by puncturing the jugular vein using $10 \mathrm{~mL}$ tubes without anticoagulant after cleaning the skin with $2 \%$ iodine alcohol. The tubes were identified with data on the municipality, the number of the animal and sex and kept in an insulated box with ice for transport. In the laboratory, the tubes containing the blood samples were centrifuged at $2.500 \mathrm{~g}$ for 10 minutes to obtain the sera that were stored in identified micro tubes and kept at $-6^{\circ} \mathrm{C}$ until the AGID test was carried out.

To carry out the PCR, urine samples were collected in falcontype tubes using the temporary respiration block technique (30 seconds) shortly after which the animal urinated spontaneously (Nozaki et al., 2011b). Before each collection the external genitalia of the rams and ewes was thoroughly cleaned with neutral detergent and water and then dried with a paper towel. The samples were identified according to the municipality, the number of the animal and sex. The tubes containing the urine samples were kept in an insulated box with ice for transport to the laboratory, were they were kept at $-20^{\circ} \mathrm{C}$ until the DNA was extracted.

To detect antibodies against $B$. ovis, the antigen was used produced by the Paraná Institute of Technology (TECPAR) that consists of soluble proteins and lipopolysaccarides, extracted from the bacteria Brucella ovis, sample Reo 198. The protocol of the supplying laboratory was followed when carrying out this test.

Agar gel immunodifusion is based on the radial migration of antigen and antibody through the agar gel, forming the antigenantibody complex that precipitates in the gel as a line of white staining between the well of the respective test serum and the antigen well (Nozaki et al., 2013).

The agar gel immunodiffusion test, as well as the solutions for preparing the agar gel, were performed as described by Nozaki et al. (2013). And the reagents used were supplied by the Paraná Institute of Technology.

Reading was made after 24.48 and 72 horas, using the indirect light with dark background system. When interpreting, the formation of a precipitation line was observed between the test sera and the positive control sera with the antigen. The test serum whose precipitation line was the same as the line formed by the positive control serum was considered positive and in the absence of precipitation line, or when the line formed was not the same as the positive control serum, the sample was considered negative.

In the polymerase chain reaction, first $10 \mathrm{~mL}$ of the urine samples were submitted to DNA extraction, using a kit appropriate for urine samples (Purelink ${ }^{\mathrm{TM}}$ Microbiome DNA Purificacion), following the steps according to the manufacturer's protocol. After extraction, the DNA obtained was quantified and then submitted to the PCR technique.

The PCR reactions were carried out using a final volume of $25 \mu \mathrm{L}$ per sample. The pair of primers used was ORF AO503 (F: 5'ATCCCCCCATCACCATAACCGAAG-3'e R: 
5'GCCTACGCTGAAACTTGCTTTTG-3') at 25 mM concentration (Xavier et al., 2010). When preparing the PCR Mix the quantities were calculated of PCR Supermix and primers that would be necessary according to the number of samples submitted to the reaction and $23 \mu \mathrm{L}$ PCR Mix and and $2 \mu \mathrm{L}$ purified DNA from the urine sample were added to each microtube, obtaining $25 \mu \mathrm{L}$ final volume. Sterile ultrapure water was used to prepare with negative control of the reaction, and as positive control DNA was used from a pure $B$. ovis colony.

The amplification parameters used during the thermocycler reaction were: denaturation at $95^{\circ} \mathrm{C}$ for 5 minutes, following by 35 cycles of denaturation at $95^{\circ} \mathrm{C}$ for 1 minute, annealing at $55^{\circ} \mathrm{C}$ for 1 minute, extension at $72^{\circ} \mathrm{C}$ for 1 minute and a final extension step at $72^{\circ} \mathrm{C}$ for 5 minutes.

The amplified product was analyzed using $2 \%$ agarose gel in a horizontal electrophoresis cube with Tris-Borate EDTA run buffer (TBE) (50 mM Tris, $50 \mathrm{mM}$ boric acid, $2.5 \mathrm{mM}$ EDTA, pH 8.0) 1X. The bands were compared with the standard molecular mass and considered positive when the molecular weight was 228bp for the AO503 primer.

The possible relation and the risk factors associated to the occurrence of positive animals on the farms were measured by the exact Fisher test and the Odds ratio with 95\% confidence interval. In the exact Fisher test the relation was considered significant when the $p$-value was less than 0.05 . The analyses were made using the Graph Pad Prism program, Version 5.0 (Trial), San Diego, CA, USA, 2007.

\section{Results and discussion}

The results obtained in the anti $-B$. ovis antibodies research by the AGID test were: 17 reactive animals, five rams and twelve ewes, while in the conventional PCR technique to detect $B$. ovis DNA six animals were positive, corresponding to three rams and three ewes and 94 animals were negative of the total of animals researched. Three animals were positive in both the tests.

Three municipalities presented at least one positive animal in the conventional PCR technique, four positive sheep, three ewes and one ram, from the municipality of Beneditinos, one ram from the municipality of Pau D'arco and one ram from the municipality of José de Freitas. These are important data, since reproducers are the main disseminators of the infection in the sheep herd.

Regarding the research on anti-B. ovis antibodies by AGID, the municipalities of Beneditinos, Pau Darco, José de Freitas and Altos were outstanding because of the presence of seropositive animals, with eleven reactive animals (eight females and three males), three reactive animals (one female and two males), two reactive animals (two females) and one female reactive animal, respectively, in each municipality. The serological diagnosis showed that the municipality of Beneditinos led with the highest number of seropositive animals.

The animals that received only bulk feed had greater probability of being positive for ovine brucellosis in the AGID test (OR $=0.05$; IC $95 \%=0.00-0.86)$, compared to the animals that received mixed feed (bulk and concentrate) (Table 1).

In the production system analysis, $40 \%(4 / 100)$ of the animals positive in the AGID test were reared in a semi-intensive rearing system $(p \leq 0.05)(O R=0.19 ; \mathrm{IC} 95 \%=0.05-0.81)$ and $24.3 \%$ of the animals seropositive for $B$. ovis received a bulk-based diet (Table 1).

Regarding reproductive problems, 33.3\% (10/30) of the animals examined presented dystocic birth $(\mathrm{OR}=4.50$; IC $95 \%=1.51$ -13.4 ), that was identified as one of the factors associated to infection by $B$. ovis (Table 1). Furthermore, $23.3 \%(14 / 60)$ of the animals had already miscarried (OR $=3.75$; IC $95 \%=1.01$ -14.1 ), so that this was also one of the risk factors associated to infection by $B$. ovis (Table 1 ).

Regarding the results for miscarriage, $23.3 \%$ of the serological samples from females were positive for anti- Brucella ovis antibodies (Table 1). However, 20 females examined and with history of repeated oestrus were negative in the serological test (AGID) and PCR. Research on animals with a history of reproductive disturbances in the state of São Paulo reported that there was no significant association between animals reactive to $B$. ovis and episodes of reproductive disturbances (Rizzo et al., 2014).

Analysis of the rearing systems adopted showed that animals reared in a semi-intensive system presented $40 \%$ positivity in the AGID test, corroborating with a study by Magalhães Neto and Gil-Turnes (1996), where the highest prevalence obtained for B. ovis was in animals reared in an intensive system. In contrast, Pinheiro Junior et al. (2009) obtained higher seropositivity in extensive systems while Clementino et al. (2007) did not observe significant difference between animals reared in extensive, semiintensive or intensive systems. For this reason, it is extremely important to identify the causes of the spread of the disease, also taking into account the type of creation animals are subjected to, since it can contribute to the spread of sheep brucellosis.

The practice of cleaning the installation is an important factor in preventing dissemination of the disease. Santos et al. (2013) reported that properties where the installation is cleaned annually presented $50 \%$ positive for ovine brucellosis. However, positivity fell $17.1 \%$ with daily and/or monthly cleaning.

Elimination of B.ovis in secretions and materials from miscarriages of infected ewes, when present in the installations, may contribute to dissemination of the infection among the animals (Clementino et al., 2007).

According to the serological technique (AGID), in the present study, seventeen animals (17\%) were reactive in the AGID test. This result was higher than that obtained in the state of São Paulo, where researchers reported $12 \%$ seropositive ewes, using the same test (Nozaki et al., 2004). Nevertheless, lower results were reported in the state of Rio Grande do Sul with 13.4\% seropositive rams (Magalhães; Gil, 1996) and 1.4\% seropositive ewes in the Northern region of Paraná (Cunha et al., 2007).

The result for the PCR showed a total of six (6\%) positive animals, three females and three males. Similarly, in another study carried out in the state of Piauí, using PCR to detect $B$. ovis, eighteen (20\%) seropositive rams were found (Costa et al., 2012). In this scenario, it is pointed out that rams with negative result in the AGID test may disseminate B.ovis through urine and semen, bearing in mind that Costa et al. (2012) found a smaller number of positive rams in the AGID test than that found in the PCR, sixteen rams were reactive and eighteen positive, respectively.

A study carried out using the AGID test in sheep in the state of Mato Grosso showed a prevalence of $6.2 \%$ (30/480), with $6.0 \%$ $(5 / 83)$ only in rams, where $77,1 \%(64 / 83)$ presented clinical alterations compatible with genital inflammation and or infectious epididymitis (Eckstein et al., 2017). 
Table 1: Risk factors associated to the occurrence of ovine brucellosis in sheep from the municipalities of the micro region of Teresina - PI, Brazil, diagnosed by the AGID and PCR methods

\begin{tabular}{|c|c|c|c|c|c|c|c|}
\hline Parameters & $\mathbf{N}$ & $\begin{array}{c}\text { AGID positive } \\
(\%)\end{array}$ & $\begin{array}{c}\text { Fisher's } \\
\text { exact }\end{array}$ & $\begin{array}{l}\text { Odds ratio } \\
\text { (IC 95\%) }\end{array}$ & $\begin{array}{c}\text { PCR } \\
\text { positive } \\
(\%) \\
\end{array}$ & $\begin{array}{c}\text { Fisher's } \\
\text { exact }\end{array}$ & $\begin{array}{l}\text { Odds ratio } \\
\text { (IC 95\%) }\end{array}$ \\
\hline \multicolumn{8}{|l|}{ Breed } \\
\hline $\begin{array}{l}\text { WDRS } \\
\text { NRSD }\end{array}$ & $\begin{array}{l}70 \\
30\end{array}$ & $\begin{array}{c}14(20.0) \\
3(10.0)\end{array}$ & 0.2618 & $\begin{array}{c}2.25 \\
(0.60-8.50)\end{array}$ & $\begin{array}{l}5(7.1) \\
1(3.3)\end{array}$ & 0.6654 & $\begin{array}{c}2.23 \\
(0.25-20.0)\end{array}$ \\
\hline \multicolumn{8}{|l|}{ Rearing system } \\
\hline Extensive & 80 & $9(11.3)$ & & & $4(5.0)$ & & \\
\hline Semi-intensive & 10 & $4(40.0)$ & 0.0345 & $\begin{array}{c}0.19 \\
(0.05-0.81)\end{array}$ & $0(0.0)$ & 1.0000 & $\begin{array}{c}1.24 \\
(0.06-24.6)\end{array}$ \\
\hline Intensive & 10 & $4(40.0)$ & 1.0000 & $\begin{array}{c}1.00 \\
(0.17-5.99)\end{array}$ & $2(20.0)$ & 0.4737 & $\begin{array}{c}0.16 \\
(0.01-3.85)\end{array}$ \\
\hline \multicolumn{8}{|l|}{ Type of installation } \\
\hline Raised floor & 40 & $4(10.0)$ & & & $2(5.0)$ & & \\
\hline Shed & 30 & $4(13.3)$ & 0.7170 & $\begin{array}{c}0.72 \\
(0.17-3.16)\end{array}$ & $0(0.0)$ & 0.5031 & $\begin{array}{c}3.96 \\
(0.18-85.7)\end{array}$ \\
\hline Bed & 30 & $9(30.0)$ & 0.2092 & $\begin{array}{c}0.36 \\
(0.10-1.33)\end{array}$ & $4(13.3)$ & 0.1124 & $\begin{array}{c}0.10 \\
(0.01-1.88)\end{array}$ \\
\hline \multicolumn{8}{|l|}{ Feeding } \\
\hline \multirow{2}{*}{$\begin{array}{c}\text { Bulky and } \\
\text { concentrate } \\
\text { Bulky }\end{array}$} & 30 & $0(0.0)$ & \multirow{2}{*}{0.0024} & \multirow{2}{*}{$\begin{array}{c}0.05 \\
(0.00-0.86)\end{array}$} & $0(0.0)$ & \multirow{2}{*}{0.1744} & \multirow[t]{2}{*}{$\begin{array}{c}0.16 \\
(0.01-2.98)\end{array}$} \\
\hline & 70 & $17(24.3)$ & & & $6(8.6)$ & & \\
\hline \multicolumn{8}{|l|}{ Type of mating } \\
\hline Field mating & 90 & $13(14.4)$ & \multirow{2}{*}{0.0637} & & $4(4.4)$ & \multirow{2}{*}{0.1090} & \multirow{2}{*}{$\begin{array}{c}0.19 \\
(0.03-1.18)\end{array}$} \\
\hline Controlled mating & 10 & $4(40.0)$ & & $(0.06-1.02)$ & $2(20.0)$ & & \\
\hline
\end{tabular}

Table 2: Risk factors associated to the occurrence of ovine brucellosis in sheep from the municipalities of the micro region of Teresina - PI, Brazil, diagnosed by the AGID and PCR methods.

\begin{tabular}{|c|c|c|c|c|c|c|c|}
\hline Parameters & $\mathbf{N}$ & $\begin{array}{c}\text { AGID positive } \\
(\%)\end{array}$ & $\begin{array}{c}\text { Fisher's } \\
\text { exact }\end{array}$ & $\begin{array}{l}\text { Odds ratio } \\
\text { (IC 95\%) }\end{array}$ & $\begin{array}{c}\text { PCR } \\
\text { positive } \\
(\%)\end{array}$ & $\begin{array}{c}\text { Fisher's } \\
\text { exact }\end{array}$ & $\begin{array}{l}\text { Odds ratio } \\
\text { (IC 95\%) }\end{array}$ \\
\hline \multicolumn{8}{|l|}{ Estrus repetition } \\
\hline Yes & 20 & $0(0.0)$ & \multirow{2}{*}{0.0205} & \multirow{2}{*}{$\begin{array}{c}0.09 \\
(0.01-1.54)\end{array}$} & $0(0.0)$ & \multirow{2}{*}{0.5967} & \multirow{2}{*}{$\begin{array}{c}0.28 \\
(0.02-5.18)\end{array}$} \\
\hline No & 80 & $17(21.3)$ & & & $6(7.5)$ & & \\
\hline \multicolumn{8}{|l|}{ Dystocic births } \\
\hline Yes & 30 & $10(33.3)$ & \multirow{2}{*}{0.0079} & \multirow{2}{*}{$\begin{array}{c}4.50 \\
(1.51-13.4)\end{array}$} & $3(10.0)$ & \multirow{2}{*}{0.3608} & \multirow{2}{*}{$\begin{array}{c}2.48 \\
(0.47-13.1)\end{array}$} \\
\hline No & 70 & $7(10.0)$ & & & $3(4.3)$ & & \\
\hline \multicolumn{8}{|l|}{ Miscarriages } \\
\hline Yes & 60 & $14(23.3)$ & \multirow{2}{*}{0.0560} & \multirow{2}{*}{$\begin{array}{c}3.75 \\
(1.002-14.1)\end{array}$} & $5(8.3)$ & \multirow{2}{*}{0.3973} & \multirow{2}{*}{$\begin{array}{c}3.55 \\
(0.40-31.6)\end{array}$} \\
\hline No & 40 & $3(7.5)$ & & & $1(2.5)$ & & \\
\hline \multicolumn{8}{|l|}{$\begin{array}{l}\text { Anti-Brucella } \\
\text { vaccination }\end{array}$} \\
\hline Yes & 0 & $0(0.0)$ & \multirow[t]{2}{*}{$\underline{ }$} & $\underline{ }$ & $0(0.0)$ & \multirow[t]{2}{*}{-} & \multirow[t]{2}{*}{ 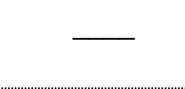 } \\
\hline No & 100 & $17(17.0)$ & & & $6(6.0)$ & & \\
\hline \multicolumn{8}{|l|}{ Water source } \\
\hline Well & 55 & $4(7.3)$ & \multirow{2}{*}{0.0065} & \multirow{2}{*}{$\begin{array}{c}0.19 \\
(0.06-0.64)\end{array}$} & $2(3.6)$ & \multirow{2}{*}{0.4045} & \multirow{2}{*}{$\begin{array}{c}0.39 \\
(0.07-2.22)\end{array}$} \\
\hline Weir & 45 & $13(28.9)$ & & & $4(8.9)$ & & \\
\hline \multicolumn{8}{|c|}{ Veterinary assistence } \\
\hline Yes & 50 & $8(16.0)$ & \multirow{2}{*}{1.0000} & \multirow{2}{*}{$\begin{array}{c}0.87 \\
(0.31-2.47)\end{array}$} & $2(4.0)$ & \multirow{2}{*}{0.6777} & \multirow{2}{*}{$\begin{array}{c}0.48 \\
(0.08-2.75)\end{array}$} \\
\hline No & 50 & $9(18.0)$ & & & $4(8.0)$ & & \\
\hline
\end{tabular}


A study to assess a species-specific nested $\mathrm{PCR}$ technique in ram semen and urine samples resulted in $49(65.3 \%)$ positive urine samples from a total of 75 samples collected from 14 rams. All the animals had been infected experimentally (Costa et al., 2013).

Due to the results found in the two diagnostic methods used in this research (AGID and PCR), where three animals positive in the PCR were negative in the AGID test, it is is recommended to use both tests to detect with more efficiency the occurrence of positive animals and to associate the results obtained with the clinical history of the animals from the farms.

\section{Conclusion}

The results obtained by the two diagnostic methods show the occurrence of ovine brucellosis in animals from the municipalities of the micro region of Teresina/ PI, Brazil. However, there was difference between the test when used alone, although PCR was outstanding as a method to confirm infection. Furthermore, it is pointed out that due to the existing transmission possibilities, prevention and control measures should be intensified especially to eliminate the risk factors associated to the disease in the region studied.

\section{Acknowledgements}

The authors thank the Federal University of Piauí; the team at the Animal Physiopathology and Reproduction Laboratory, the National Council for Scientific and Technological Development (CNPq), for the research grant.

\section{References}

COSTA, E. A.; SANT'ANA, F.M.; CARVALHO, C.J.S.; MOUSTACAS, V.S.; SILVA, S.M.M.S.; PAIXÃO, T.A.; SANTOS, R.L. Diagnosis of Brucella ovis infection by serology and PCR in urine samples from naturally infected rams in the state of Piauí. Arquivo Brasileiro de Medicina Veterinária e Zootecnia, v. 64, n. 3, p. 751-754, 2012.

COSTA, L. F.; NOZAKI, C.N.; LIRA, N.S.C.; ANTUNES, J.M.A.P.; XAVIER, M.N.; COSTA E.A.; PAIXÃO, T.A.; SANTOS, R.L.; MEGID, J.. Species-specific nested PCR as a diagnostic tool for Brucella ovis infection in rams. Arquivo Brasileiro de Medicina Veterinária e Zootecnia, v. 65, n. 1, p. 55-60, 2013.

CLEMENTINO, I. J.; ALVES, C. J.; AZEVEDO, S. S.; PAULIN, L. M.; MEDEIROS, K. A. Inquérito soro-epidemiológico e fatores de risco associados à infecção por Brucella ovis em carneiros deslanados do semi-árido da Paraíba. Pesquisa Veterinária Brasileira, v. 27, n. 4, p. 137-143, 2007.

CUNHA FILHO, L. F. C.; LEUZZI JUNIOR, L. A.; SILVA, L. C.; AGOTTANE, J. V. B.; OKANO, W.; STERZA, F. M. A.; ZANIN, R. Ocorrência de ovinos reagentes à prova de imunodifusão em gel de ágar para Brucella ovis em propriedades da região norte do Paraná. UNOPAR Cientifica Ciencias Biologicas e da Saude, v. 9, n. 1, p. 67-70, 2007.

ECKSTEIN, C.; MOUSTACAS, V. S.; LOPES, L. B.; MOL, J. P. S.; GOMES, S. C.; SANTOS, R. CASTRO, B. G.; SANTOS, R. L. Differential diagnosis of infectious reproductive diseases in sheep flocks of Mato Grosso State, Brazil. Small Ruminant Research, v. 153, p. 158-162, 2013.

LIMA, A. M. C. Brucelose ovina: soroprevalência e análise dos fatores de risco nos Estados do Rio Grande do Norte, Paraíba e Sergipe. Sobral, 2015. 76 f. Dissertação (Mestrado em Zootecnia) - Universidade Estadual Vale do Acaraú. 2015.

MAGALHÃES, N. A.; GIL, T. C. Brucelose Ovina no Rio Grande do Sul. Pesquisa Veterinária Brasileira, v. 16, n. 2/3, p. 75-79, 1996.

MENDONÇA, C. E. D.; MUNHOZ, A. D.; BEZERRA, R. A.; GUIMARÃES, L. A.; ALBUQUERQUE, G. R.; MELO, C. B. Brucella ovis em ovinos: soropositividade e fatores de risco. Ciência Animal Brasileira, v. 18, p. 1-9, e-41635, 2017.

MOUSTACAS, V. S.; SILVA, T. M. A.; COSTA, L. F.; XAVIER, M. N.; CARVALHO JUNIOR, C. A.; COSTA, E. A.; PAIXÃO, T. A.; SATOS, R. L. Species-specific multiplex PCR for the diagnosis of Brucella ovis, Actinobacillus seminis, and Histophilus somni infection in rams. Veterinary Research, v. 9, n. 1, p. 51-57, 2013.
NOGUEIRA, A. H. C.; FERRAR, C. I. L.; CURCI, V. C. L. M. Brucelose Ovina (Brucella ovis). Apta Regional, v. 16, p. 55-59, 2006.

NOZAKI, C. N.; AZEVEDO, H. C.; LIRA, N. S. C.; RODELLO, L.; AUGUSTO FILHO, O.; DASSO, M. G.; BICUDO, S. D.; ANTUNES, J. M. A. P.; MEGID, J. Brucella ovis REO 198 natural and experimental infection in Santa Inês rams from Brazil. Semina: Ciências Agrárias, v. 34, n. 2, p. 759-764, 2013.

NOZAKI, C. N.; LIRA, N. S. C.; AUGUSTO FILHO, O.; AZEVEDO H. C.; RODELLO, L.; DASSO, M. G.; BICUDO, S. D.; ANTUNES, J. M. A. P; MEGID, J. Rapid serum agglutination and agar gel immunodiffusion tests associated to clinical. Ciência Rural, v. 41, n. 8, p. 1441-1446, 2011a.

NOZAKI, C. N.; MEGID, J.; LIMA, K. C.; SILVA JUNIOR, F. F.; VELOSO, C. S. Comparação das técnicas de imunodifusão em gel de Ágar e Elisa no diagnóstico da Brucelose Ovina em cabanhas da região centro-oeste do Estado de São Paulo. Arquivos do Instituto Biológico, v. 71, n. 1, p. 1-5, 2004.

NOZAKI, C. N.; SALGADO, V. R.; LIRA, N. S. C.; AUGUSTO FILHO, O.; DASSO, M. G.; ANTUNES, J. M. A. P. MEGID, $J$. Adaptation and evaluation of polymerase chain reaction for Brucella ovis detection in semen, urine and organs of rams experimentally infected. Arquivo Brasileiro de Medicina Veterinária e Zootecnia, v. 63, n. 6, p. 1591-1594, 2011b.

PINHEIRO JUNIOR, J. W.; OLIVEIRA, A. A. F.; MOTA, R. A.; AGOTTANI, J. V.; JESUS, E. M.; ASSIS, S. T.; OLIVEIRA, C. Z. Ocorrência de ovinos sororeatores para Brucella ovis no Estado de Alagoas, Brasil. Veterinária e Zootecnia, v. 16, n. 3, p. 500508, 2009.

RIZZO, H.; GREGORY, L.; BERALDI, F.; CARVALHO, A. F.; PINHEIRO, E. S.; PAULIN, L. M. Ocorrência de anticorpos antiBrucella ovis em ovinos com histórico de distúrbios reprodutivos no estado de São Paulo, Brasil. Arquivos do Instituto Biológico, v. 81, n. 2, p. 99-106, 2014.

SANTOS, F. A. HIGINO, S. S. S.; AZEVEDO, S. S.; COSTA, D. F.; FARIAS, A. E. M.; ALVES, F. A. L.; PAULIN, L. M.; ALVES, C. J. Caracterização epidemiológica e fatores de risco associados à infecção por Brucella ovis em ovinos deslanados do semiárido paraibano. Pesquisa Veterinária Brasileira, v. 33, n. 4, p. 459-463, 2013.

XAVIER, M. N.; SILVA, T. M. A.; COSTA, E. A.; PAIXÃO, T. A.; MOUSTACAS, V. S.; CARVALHO JUNIOR, C. A.; SANT'ANNA, F. M.; ROBLES, C. A.; GOUVEIA, A. M. G.; LAGE, A. P.; TSOLIS, R. M.; SANTOS, R. L. Development and evaluation of a speciespecific PCR assay for the detection of Brucella ovis infection in rams. Veterinary Microbiology, v. 145, p. 158-164, 2010. 